Cornell University Law School Scholarship@Cornell Law: A Digital Repository

$10-2016$

\title{
Book Review of The Quiet Power of Indicators: Measuring Governance, Corruption, and the Rule of Law
}

Sital Kalantry

Cornell LawSchool, sk49@cornell.edu

Follow this and additional works at: http://scholarship.law.cornell.edu/clsops_papers

Part of the Models and Methods Commons, and the Rule of Law Commons

\section{Recommended Citation}

Kalantry, Sital, "Book Review of The Quiet Power of Indicators: Measuring Governance, Corruption, and the Rule of Law" (2016). Cornell Law Faculty Working Papers. Paper 123.

http://scholarship.law.cornell.edu/clsops_papers/123 
Published in the Nordic Journal of Human Rights

Vol 34, No. 3, 226-227 (2016)

Book Review of The Quiet Power of Indicators: Measuring Governance, Corruption, and the Rule of Law by Sally Engle Merry, Kevin E. Davis, and Benedict Kingsbury, eds. (Cambridge University Press 2015).

We live in a world of indicators. Universities are ranked by indicators. Governments determine legislative and economic policy using indicators. Human rights organizations use indicators to draw attention to human rights violations. Scholarship dedicated to the study and critique of indicators is booming. Sally Engle Merry, Kevin E. Davis, and Benedict Kingsbury's new edited volume makes a unique contribution to this field by focusing on a specific type of indicator - "governance indicators." These indicators typically measure the economic performance of countries and assess the functioning of their government institutions.

Unlike some edited collections, this new volume has a refreshing consistency across each chapter. Each chapter engages with one specific indicator. Some chapter authors examine a global indicator in general terms. Christopher G. Bradley's chapter, for example, focuses on the historical development of a global indicator used by Freedom House to rank countries on the basis of civil and political openness (pp. 27-74). Other chapter authors analyze the application of a specific governance indicator in a given country. Migai Akech does so when he investigates the use and application of corruption indicators on-the-ground in Kenya (pp. 248-283).

In the introduction to the book, the editors of the volume suggest a useful framework to understand indicators. According to them, the trajectory of indicator development involves five stages - conceptualization, production, use, impact, and contestation (pp. 10-17). The last stage describes how indicators are challenged.

The chapter authors raise a number of critiques of indicators. I categorize these critiques using the first four stages of the indicator development framework set forth by the book editors. Through this lens, we are better able to determine whether (and how) the problems identified by the chapter authors can be overcome. This analysis also reveals that some of the concerns raised in the book are not about the use of indicators generally, but instead they are objections to the particular context in which governance indicators are deployed.

The first stage of the indicator development trajectory is conceptualization. While the book editors identify it as one stage, this process actually involves two discrete steps. This stage emphasizes that the person who designs an indicator inscribes a set of values and a world-view in the process. Prada Uribe's chapter identifies problems with indicators at this level. She argues that indicators used by development agencies such as World Bank and IMF assume a model of development that both prioritizes certain economic polices over others and fails to recognize the importance of human rights to development (pp. 150-151). Responding to Uribe's 
critique would require major policy shifts whereby development agencies adopt and promote a different model of economic growth. This critique is more about the values imbued in certain governance indicators rather than how they are applied.

The second discrete process within the conceptualization phase involves the translation of these broad values into measureable concepts. There is sometimes a "slippage" problem at this phase. This means that the proxy chosen to measure a concept only partially measures it. For example, Akech points out that Transparency International's indicator to measure corruption in Kenya was inadequate because it only measured one form of corruption-bribery. (p. 249). The typical response to this type of critique is to take greater care in translating values into measurable concepts. However, it may be impossible to measure a concept precisely, as the data often does not exist and is too expensive to generate.

The next and second broad stage identified by the editors in the indicator development phase is production. Production involves applying data to a specific concept being tested. The data is typically already in existence and is collected by sources such as the census. Sometimes those who conceptualize the indicator may have resources to develop their own primary data. Serban's critique on the rule of law indicators in Romania loudly rings of the problems at this stage. The data relied on by these rule of law indicators was a survey of perception data. However, Serban points out that many people in Romania consider these indicators unreliable because they measure only perception and that perception presumably does not reflect reality (p.216). Responding to this critique requires using more reliable data or data that is a better fit with the indicator. The trouble, as noted above, is that this data may simply not exist. Another author, Musaraj, notes that the distribution of labor in regard to governance indicators is unfair. The Global North designs indicators and the Global South is required to spend the time and resources to apply them (p. 240). Musaraj's critique suggests that agencies should reimburse countries for these costs.

The third phase of indicator deployment is its use. Organizations or governments that have commissioned indicators will use them for a number of different purposes. Usually, an indicator's use is known at the time of its conceptualization. Many of the indicators discussed in the book, for instance, were developed for the purpose of measuring a country's economic and political position. If a country fares poorly under these indicators, it may receive less funding from the Global North. Uribe raises further objections at this level. She argues that this practice has allowed development organizations located in the Global North to wield power and control over countries in the Global South (p. 150). Moreover, she argues that this structure suggests that developing countries are to blame for their own underdevelopment and poverty. (p.140). These concerns while important are not an assault on indicators more generally; they oppose the context in which governance indicators play out. 
Sarfaty's chapter points out that sometimes indicators may be used in ways not predicted at the conceptualization stage. In her review of a corporate accountability index, Sarfaty reveals that while the index was developed for nonprofit organizations to hold corporations accountable, it has been co-opted by corporations to produce self-compliance reports (p. 118). One could argue that this suggests the indicator has been successful if corporations have adopted it. Sarfaty instead sees this as "box-ticking" and "superficial compliance." If so, the problem may not be that corporations are now using the indicator, but rather that the indicator has little teeth and the standards it sets are too low.

The fourth phase involves measuring impact. In some cases, the indicators themselves set baselines to measure impact. Other indicators allow impact to be readily observed. For example, if the number of children attending primary school in any given country increases from one year to another, a positive change in the country is likely to have occurred. Yet indicators, particularly those produced by non-profit organizations, will have little impact on government behavior if they are ignored by government agencies. Akech makes this point after analyzing Kenya's bribery index, which has yet to influence the Kenyan government's behavior (p.249). Additionally, an unintended impact of governance indicators is that countries will adopt policies that will maximize indicator performance, but neglect to take into account broader priorities and constituencies (p.319).

Filtering these critiques through the lens offered by the editors in their introduction demonstrates that many of the problems identified by the chapter authors are not inherent in the process of governance indicator development. Uribe points out that governance indicators perpetuate the global inequalities between countries and impose a fixed-economic agenda on Global South countries. These are not inherent problems with indicators, but instead are specific concerns about the power dynamics between those who deploy indicators and those who are governed by them in this context. Where governance indicators are used there is an asymmetrical bargaining power between those who are judging and those who are being judged.

On the other hand, it may be possible to address some problems identified by the chapter authors by tinkering with the indicator development process. If indicators are being co-opted by those that they intend to regulate, then they should be strengthened. If indicators do not adequately measure concepts, then new ones should be formulated. If reliable data does not exist to measure certain concepts, then those with resources should focus on developing it.

Indicators offer a useful tool to convert massive amounts of information into manageable pieces. They set baselines against which progress can be measured. While problems of "slippage" or lack of data can arise whenever indicators are deployed, the book points out that governance indicators are problematic because they raise additional concerns because of the context in which they are deployed. Where governance indicators are used, those who have power regulate those with 
less power. However, that is not the case in other situations where indicators are used. For example, in the context of human rights indicators, typically those with less power (non-profit organizations) attempt to change the behavior of those with greater power (countries). The indicator development framework identified by the editors is a useful tool for distinguishing those critiques raised by chapter authors that relate to the context of governance indicators and concerns about the technical process of indicator development, application, and use. The latter concerns are easier to address than the former critiques. 